Check for updates

The BMJ

Cite this as: $B M J 2020 ; 371: m 3891$ http://dx.doi.org/10.1136/bmj.m3891 Published: 06 October 2020

\title{
Covid-19: Only half of 16000 patients missed from England's official figures have been contacted
}

\section{Elisabeth Mahase}

Details of nearly 16 ooo cases of covid-19 were not transferred to England's NHS Test and Trace service and were missed from official figures because of an error in the process for updating the data.

England's health and social care secretary, Matt Hancock, told the House of Commons on Monday 5 October that after the error was discovered on Friday 2 October "6500 hours of extra contact tracing" had been carried out over the weekend. But as at Monday morning only half $(51 \%)$ of the people had been reached by contact tracers.

In response, Labour's shadow health secretary, Jonathan Ashworth, said, "Thousands of people are blissfully unaware they have been exposed to covid, potentially spreading this deadly virus at a time when hospital admissions are rising and we are in the second wave. This is not just a shambles, it is so much worse."

The missed cases were added to the daily figures for the weekend, meaning that 22961 cases were reported on Sunday 4 October and 12872 were reported on Saturday.

Reports indicated that the problem may have been caused by the row limit on Microsoft's Excel spreadsheet software, which caused numbers sent from one laboratory to be missed off.

Hancock would not confirm the cause of the technical issue but said that he had already decided to replace the system at fault in July. "I commissioned a new data system to replace the legacy one, and the contracts were awarded in August and the work on the upgrade is already under way," he told MPs.

The Guardian reported that the error occurred when one laboratory sent its daily test report to Public Health England in a CSV file. ${ }^{1}$ Although these files can be any size, an Excel spreadsheet has a limit of 1048576 rows, or 65536 if an older version of the software was being used. When a file longer than that is opened, the rows that exceed the maximum are cut off, meaning once that laboratory had performed more than a million tests, its reports were not seen by PHE.

Commenting on the error, Peter Bannister, executive chair of the Institution of Engineering and Technology Healthcare Sector, said, “It's widely known within medical device development that the use of commercial off-the-shelf products, such as Excel, requires additional testing to ensure that they are able to meet the stringent requirements of use in a healthcare setting.

"In particular, regulatory authorities such as the FDA in the US have called out the limitations of Excel when applied to storing and manipulating medical data and furthermore have issued guidance on validation and risk management for these products if they are to be used in such a safety critical manner."

The error came as the Labour Party's leader, Keir Starmer, said that the prime minister had "lost control” of covid-19, with no clear strategy for beating it. Speaking to the Observer, Starmer set out his five point plan for covid-19, which starts with publishing the criteria for local restrictions, as the German government did. Secondly, he said public health messaging should be improved by adding a feature to the NHS covid-19 app so people can search their postcode and find out their local restrictions.

Starmer has also said he would fix the contact tracing system by investing in NHS and university laboratories to expand testing and at the same time put local public health teams in charge of contact tracing in their areas. Routine regular testing in high risk workplaces and high transmission areas would then be carried out, with results within 24 hours.

Additionally, Starmer would outline a vaccine manufacturing and distribution programme ready for when a vaccine is approved.
1 Halliday J, Campbell D, Walker P, Sample I. England covid cases error means 50000 contacts may not have been traced. Guardian. 5 Oct 2020. https://www.theguardian.com/world/2020/oct/05/england-covid-cases- error-unknown-how-many-contacts-not-traced-says-minister.

This article is made freely available for use in accordance with BMJ's website terms and conditions for the duration of the covid-19 pandemic or until otherwise determined by BMJ. You may use, download and print the article for any lawful, non-commercial purpose (including text and data mining) provided that all copyright notices and trade marks are retained. 